\title{
The Freedom To Do As We Please: A Strong Value Pluralist Conceptualization of Negative Freedom
}

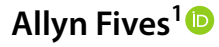 \\ Accepted: 3 September 2021 \\ (c) The Author(s) 2021
}

\section{Introduction}

The value pluralist thesis is that we can be faced with moral conflicts and we have not identified the general rule for their resolution. Moral reasons for action (whether values, or ends, or claims, or principles, and so on) are not only varied but also potentially conflicting. And when we do resolve a moral conflict, the item not acted upon does not fade away: it remains a reason for action. In the modern era, Isaiah Berlin provides what is arguably the definitive statement of that position (2004 [1958]). He also offers a value pluralist account of freedom. The requirement to protect freedom from interference in our choices and activities, so-called negative freedom, is one reason for action (Berlin 2004, [1958], pp. 169-70); and it is violated by 'obstacles to possible choices and activities' (Berlin 2004a [1969], p. 32). As a value pluralist, Berlin accepts that the requirement to protect negative freedom can come into conflict with other reasons for action, and that on occasion there may be overriding reasons to restrict negative freedom. At the same time, to act in this way is wrong, and this is the case because our commitment to protect negative freedom still provides us with a reason for action. For example, it is for that reason wrong to remove the option of violent extremism, including when we do for the good of the extremist (Fives 2019; 2020).

In this paper, I progress that line of argument in the following three directions. In the first section, I show that, although Berlin conceptualizes negative freedom broadly, as the freedom from interference in our possible choices and activities, this encompasses a narrower conception, namely the freedom to do as we please. As negative freedom is the freedom to do as we please (and much else besides), it is the freedom to act in ways that are, inter alia, intolerant, or heteronomous, or that simply violate the norms of our community, whatever they happen to be. When we do act in any of these ways, there may be a moral conflict as a result, and it may be that it is right, all things considered, to interfere with these choices.

Allyn Fives

allyn.fives@nuigalway.ie

1 National University of Ireland, Galway, Galway, Ireland 
However, even if the interference is justified all-things-considered, it is wrong to stop us from doing as we please. That is, while interference with negative freedom is a wrong, there will always be some restrictions placed on negative freedom, and this is to be justified by an all things considered judgement.

My second line of argument is that this conclusion is deemed unacceptable even by the leading figures of contemporary value pluralism, and this is explained by a clash between a strong and a weak version of value pluralism. While Berlin insists there is no general rule for the resolution of moral conflicts, William Galston (2005) and George Crowder (2004), like Joseph Raz before them (2009 [1979]), each introduce a general rule of their own. Liberal value pluralists thus try to show that the requirement to protect negative freedom ceases to have value when it is incompatible with either liberal toleration of diversity, as Galston maintains, or the liberal commitment to personal autonomy, as contended by Crowder. I argue that they fail to reject Berlin's strong version of value pluralism, and so they do not undermine the thesis that we are free to do as we please.

In the final section of this paper, I argue that this thesis also is not called into question by two important recent developments within value pluralism: political realism and modus vivendi. That is, strong value pluralism does not support the conclusion that (i) we are not free to do anything that calls into question what Bernard Williams calls an 'acceptable solution' to the problem of legitimacy (2005, p. 4), or that (ii) what John Gray calls an illiberal modus vivendi can 'crowd [...] out' or 'exclude [...] altogether' the requirement to protect negative freedom as a reason for action (1998, p. 20). Hence, what strong value pluralism can show is that preventing others from doing as they please is a wrong even when it is justified. As a result, it provides a distinctive contribution to the critical analysis of political institutions and political practice, one that remains alive to the wrongs done when we resolve moral conflicts.

\section{Berlin's strong value pluralist conception of negative freedom}

In 'Two Concepts of Liberty,' Berlin sets out his conception of negative freedom (or liberty) as follows:

I am normally said to be free to the degree to which no man or body interferes with my activity. Political liberty in this sense is simply the area within which a man can act unobstructed by others [...] Being free in this sense I mean not being interfered with by others. The wider the area of non-interference the wider my freedom. (2004 [1958], pp. 169-70)

It is one thing to describe the freedom from interference. However, Berlin is using the concept of negative freedom to also help make sense of the normative question of coercion and its justification. Hence, 'oppression is the part that I believe to be played by other human beings, directly or indirectly, with or without the intention of doing so, in frustrating my wishes' (ibid., p. 170). Not only that, 
Berlin also offers his own argument for why the requirement to protect negative freedom is not only a value but a value of considerable significance:

we are faced with choices between ends equally ultimate, and claims equally absolute, the realisation of some of which must inevitably involve the sacrifice of others. Indeed, it is because this is their situation that men place such immense value upon the freedom to choose, for if they had assurance that in some perfect state, realisable by men on earth, no ends pursued by them would ever be in conflict, the necessity and agony of choice would disappear, and with it the central importance of the freedom to choose. (ibid., pp. 213-4).

We place 'immense value' on the 'freedom to choose,' Berlin is saying, because we are faced with the 'agony of choice.'

Such a concept can be conceptualized in narrower or broader terms. Narrowly conceived, it is the freedom from interference in our wants and desires. Broadly conceptualized, it is 'the absence of obstacles to possible choices and activities' (2004 [1969], p. 32). For Berlin, the narrower conception is insufficient on its own, because we may achieve freedom from frustration in satisfying our desires simply by removing those of our desires that are difficult to satisfy. This may be a good guide to our contentment without it saying anything of our freedom. That is why the broader conceptualization is needed: it matters, for our freedom, that we have a broader rather than a narrower range of options, and that they are options that we value (Berlin 2004 [1958], p. 177 n1). Nonetheless, the broader conception includes the narrower one. That is, insofar as our negative freedom (broadly conceived) is guaranteed then we are free to do as we please (and much more besides). Being free to do as we please is itself a genuine dimension of freedom. An additional point is that, although the requirement to protect negative freedom is a reason for action, nonetheless, Berlin accepts, it is not the only reason for action and it need not be a conclusive reason for action. Hence, a society may be required to violate negative freedom. A political community will interfere with our choices and activities, and strive to prevent us from taking certain options, and do so by various means, including the threat of coercion. Berlin accepts that this will happen, and sometimes with justification, but nonetheless insists that it is a wrong: a violation of freedom. As Berlin puts it, 'law,' all law, even law whose purpose is to protect liberty, 'is always a fetter' (ibid., p. 170).

That Berlin believes both that all interference is wrong and yet that it may be justified reflects the fact that his is a value pluralist conceptualization of negative freedom. For value pluralists, we can be faced with real moral conflicts. In a moral conflict, we have a reason to do one thing (e.g., not interfere with $\mathrm{X}$ 's choices), a reason to do another (e.g., keep Y safe from X's malicious, extremist intentions), we can do either, but in the given situation we cannot do both. As Berlin says, "we are faced with choices between ends equally ultimate, and claims equally absolute, the realisation of some of which must inevitably involve the sacrifice of others' (Berlin 2004 [1958], p. 213). The underlying assumption here is that something can be a reason for action without its being a conclusive reason. That is how we can have two (or more) reasons for action that are incompatible. 
Not only that, when faced with such a moral conflict it is not possible either to reduce the diversity of moral reasons to some master value or to rank order moral reasons (see Kekes 1993, p. 19; Williams 1981[1979], p. 80). Value pluralists therefore reject monist claims to have discovered the general rule to resolve moral conflicts, such as the utilitarian argument that utility is the 'ultimate appeal' on all ethical questions (Mill 1985 [1859], p. 70). As Berlin emphasizes, although we have to make decisions in these cases, we must make do without such a general rule: 'One or other of these conflicting rules or principles must, at any rate in practice, yield: not always for reasons that can be clearly stated, let alone generalised into rules or universal maxims. Still, a practical compromise has to be found' (2004 [1958], pp. 172-3).

Not only is there no one reason for action that always has priority over others, but also when we decide between conflicting claims, the item not acted upon is not somehow 'eliminate[d]' (Williams 1965, p. 117). Whatever we do in a moral conflict, even when our decision is justified all-things-considered, we do something wrong: something 'intrinsically bad' (Raz 1986, p. 405), something we, who have acted in this way, should 'regret' (Williams 1965, p. 117). As Berlin makes clear, there may be many good reasons to infringe on people's negative freedom, for a start because often we exercise our negative freedom by using force to overcome obstacles hampering us from acting on our choices: 'Such acts may be unjust, they may involve violence, cruelty, the enslavement of others, but it can scarcely be denied that thereby the agent is able in the most literal sense to increase his own freedom' (2004 [1958], p. 187). The exercise of negative freedom also can involve the wrong of omitting to do what we ought to do, for example when we fail to help those unable to help themselves. And there may be conclusive reasons, in a given situation, to restrict negative freedom, for example so as to prevent people engaging in violence. Even if we were justified in doing so, however, this does not change the fact that we have done something wrong. We are giving up some freedom so as to attain some other valued goal. For example, Berlin says that to 'avoid glaring inequality or widespread misery I am prepared to sacrifice some, or all, of my freedom [...] but it is freedom that I am giving up for the sake of justice or equality or the love of my fellow men' (ibid., p. 172).

When there are reasons to sacrifice negative freedom we are faced with a genuine moral conflict: we ought to protect negative freedom but at the same time we ought to interfere with it in the name of some other moral claim. And as we saw, Berlin emphasizes we have not identified the general rule to resolve that or any other genuine conflict. Nonetheless, as he makes clear in a later article co-authored with Bernard Williams, we do have rational resources for making such a decision. When faced with moral conflict, what is needed is not a 'debate about logical possibilities,' but instead a 'practical decision,' which 'could not in principle be made completely algorithmic:' a 'concrete decision' about 'social and historical reality' (Berlin and Williams 1994, p. 307, p. 309; see also Williams 2009, p. 23). We can offer these reasons to others, so that the answer to the question of which value 'has more weight' in a given 'set of circumstances' 'could be the subject of discussion and potential agreement by reasonable people' (Berlin and Williams 1994, p. 307). To reiterate, making such a decision involves practical reasoning rather than theoretical 
reasoning. And this is so because moral theory has not identified the general rule for the resolution of moral conflicts.

My argument is that this represents a 'strong' version of value pluralism. Its strength is evident when compared with the 'weak' version of value pluralism we see not only in Galston's and Crowder's work discussed later, but also the arguments of Joseph Raz. As he says in The Morality of Freedom, Raz accepts that some conflicts are 'real conflicts between independent moral considerations, rather than [...] merely conflicting partial judgements which simply give way without trace to an all-things considered judgement' (1986, p. 404). That is why we often have to do something wrong in order to do what is right. However, despite his value pluralism, Raz does claim to have identified the general rule for resolving some moral conflicts, namely those that arise in connection with authoritative directives. In issuing an authoritative directive, Raz says, 'by using power to tell a person to $\phi$, the power utterance is a reason for that person to $\phi$ and also a second-order reason for not acting on (all or some) reasons for not $\phi$-ing' (2009 [1979], p. 18). For example, if we are obliged to restrict the negative freedom of intolerant extremists, then this requires us to exclude (to not act on) the requirement to protect negative freedom. Not only that, there is, he says, a 'general principle of practical reasoning which determines that exclusionary reasons always prevail' (2009 [1975], p. 40). That is, an authoritative directive is a higher level reason and, as a general rule, it will 'always prevail' over the reasons for action it excludes. Therefore, even if the excluded reason (e.g. the requirement to protect negative freedom) is more weighty, it cannot override the higher level reason. This is a weak version of value pluralism, as it employs a general rule for resolving some moral conflicts. The implication of that general rule is important: if the requirement to protect negative freedom is excluded by the authoritative directive, then it ceases to be a reason for action, and we are no longer caught on the horns of a dilemma.

Berlin's value pluralism is of the strong variety because it denies that there is such a general rule for resolving moral conflicts. Specifically, he rejects the idea that any one reason for action is always conclusive, and so overrides all others. That is why Berlin does not accept 'that individual freedom is, even in the most liberal societies, the sole, or even the dominant criterion of social action' (2004 [1958], p. 214). This point will be very important as I develop my argument in this paper. It means that Berlin does not, and indeed could not without contradiction, say that we are required to live together in a particular kind of liberal society, namely one where negative freedom is the preeminent value. This is so, even though Berlin attempts to show that, because of the reality of moral conflict, negative freedom has, as we have already seen, 'immense value.' Berlin is saying that negative freedom is of immense value because we must choose 'between ends equally ultimate, and claims equally absolute, the realisation of some of which must inevitably involve the sacrifice of others.' However, there is some controversy over how to interpret this passage. According to Gray, for example, Berlin's intention is to ground a liberal political morality that gives 'preeminence' to the 'promotion of negative liberty' (2013 [1996], p. 67). In contrast, William Galston accepts that, although Berlin is giving 'special status to individual liberty,' nonetheless, on occasion other commitments are allowed 'to dominate negative liberty' (1999, p. 773). In fact, Galston is correct 
here. Although Berlin does give a special status to negative freedom, he does not give it preeminence: Berlin is not arguing that, as a general rule, the requirement to protect negative freedom has priority over other reasons for action.

The implications of Berlin's strong pluralist defense of freedom are profound and even, for many, unsettling. Berlin's argument for the importance of negative freedom starts from the fact that we are forced to choose between genuine goods. This is what occasions the 'agony of choice.' However, it does not follow that, for Berlin, we are free only to do those things that are morally right, or good, or tolerable. He is clear in rejecting the Kantian idea that freedom 'is not freedom to do what is irrational, or stupid, or wrong' (Berlin 2004 [1958], p. 191). As Gray argues in his interpretation of Berlin:

the intrinsic value of freedom [...] is in its embodiment of the 'basic freedom' of choice itself - not the rational choice among genuine goods and worthwhile options that is designated by autonomy, but choice simpliciter. Such choice may be capricious or whimsical, perverse or unreasonable, quixotic or selfdestructive: it remains choice, and, as such the source of the value of negative freedom. (Gray 2013 [1996], p. 65)

The point being made here is not that Berlin does not appreciate the value of our doing what is right, good, and noble. He clearly does. He also accepts that the Kantian ideal of freedom is also a genuine moral commitment, and at times can override negative freedom. But he also insists that negative freedom is something distinct and is a genuine moral commitment in its own right.

If the requirement to protect negative freedom is a reason for action, and if this is so regardless of the ends to which negative freedom is employed, then we are indeed free to do what is morally wrong, including what is perverse or unreasonable. That is, it is morally wrong to take away these options. This does not alter the fact that the options are bad. Their being bad options may go to show that, all things considered, they should be prevented. But again, such interference is, in the first instance, a wrong. But is it reasonable to say that extremism is an option we are free to choose? Extremists are moved by hatred for those who do not share their beliefs, they refuse to tolerate diversity, and instead assume they can legitimately use violence against those they abhor (Schmid 2013, pp. 23-4; Midlarsky 2011, p. 346). Therefore, extremism is potentially harmful to others. Some would argue that we are not free to harm others, and therefore, we do not infringe the freedom of the extremists when we stop them from violently attacking those they abhor (Mill 1985 [1859], p. 68). That is not Berlin's argument. He accepts, as we saw, that we can increase our negative freedom by using injustice, violence, cruelty, and the enslavement of others. We are free to harm others, therefore. Berlin is not saying that we could never justifiably prevent extremist violence. His point is that when we do so we violate freedom.

Extremism is also potentially harmful to extremists themselves, and some responses to extremism are paternalistic. Paternalists exercise power over others, for their own good, and without their consent (Fives 2017; 2018). This is the case with compulsory anti-radicalization programs for those thought to be vulnerable to radicalization. Again, some will say that, if we are justified treating others paternalistically, it must be that we do not in this way restrict their liberty. For example, it is 
argued that we are required to protect the liberty only of those who are capable of self-government, and we should treat paternalistically only those who are incapable of self-government (Mill 1985 [1859], p. 147). In contrast, for Berlin, paternalism does violate freedom:

It is one thing to say that I may be coerced for my own good, which I am too blind to see: this may, on occasion, be for my benefit; indeed it may enlarge the scope of my liberty. It is another to say that if it is my good, then I am not being coerced, for I have willed it. (Berlin 2004 [1958], p. 180)

Even when paternalistic infringements are justified, for example for those who lack competence (those too blind to see their own good), they still count as violations of negative freedom. But what this line of argument clearly assumes is that, in the first place, we are free to act in ways that are bad for us even when we lack competence.

As the requirement to protect negative freedom is one moral commitment among others, and as there is no general rule to resolve conflicts between it and other reasons for action, then we are free to do as we please. This does not mean that there should never be any restrictions on negative freedom. Rather, although violating negative freedom is always a wrong, it can, on occasion, be justified all things considered. Strong value pluralism enables us to perceive such wrongs because it 'affirms the freedom to choose what is not, in the end, choiceworthy' (Gray 2013 [1996], p. 67). We have seen that others reject this idea, saying we are not free to harm others, we are not free to harm ourselves when we lack competence, and so on. However, approaching freedom in this way raises serious concerns, as Berlin was quick to point out. His worry is that, if freedom 'is not freedom to do what is irrational, or stupid, or wrong,' then a 'law which forbids me to do what I could not, as a sane being, conceivably wish to do is not a restraint on my freedom' (Berlin 2004 [1958], p. 191, pp. 194-5). This creates a paradox whereby coercion, if it is deemed legitimate, does not infringe freedom. If our society is designed on the basis of certain values, say the values of negative freedom, autonomy, and toleration among others, it must be decided how to treat those who refuse to adhere to these values, for example, because of violent extremism. There is a diversity of possible policy responses to such behavior. Not all involve restricting negative freedom. And what strong value pluralism shows is that there is a moral difference between policy responses that do and do not remove options: those that remove options violate liberty. The strong value pluralist account of negative freedom, therefore, highlights something of great moral significance: no matter how legitimate a society, it is wrong to be prevented from acting in ways contrary to its values.

\section{Weak value pluralism}

For Berlin's strong value pluralist conception of freedom, we are free to do as we please (and much more besides). I have referred to this as the unsettling implication of Berlin's strong value pluralism. As we shall see now, for many of those who claim to follow in Berlin's footsteps, it has proven to be the most controversial feature of 
his work. And the explanation can be found in the distinction between strong and weak value pluralism.

As a value pluralist, William Galston maintains 'there are no comprehensive "lexical orderings" among types of goods' (2005, p. 11, p. 13). In addition, we can be faced with 'competing demands [that] are independent of one another and authoritative,' and so if we 'reach an all-things-considered judgment that endorses one side of the argument, it may well be the case that we will set aside something of genuine value' (ibid., pp. 17-8). Berlin would be in agreement with this much of Galston's approach to moral conflict. Not only that, in some of Galston's early work, he is also happy to defend Berlin's conception of negative freedom. There is, Galston maintains, 'a presumption against' coercion, 'grounded in the pervasive human desire to go our own way in accordance with our own desires and beliefs' (1999, p. 773, p. 776). However, over the following years he begins to make a distinction between Berlin's conception of negative freedom and a conception of liberty associated with the toleration of diversity, what Galston calls expressive liberty. Indeed, he comes to the conclusion that expressive liberty is the most fundamental of all liberties and that the explanation for this is to be found in value pluralism itself. It is this that represents Galston's weak version of value pluralism.

To start with, value pluralism sets before us those things that are, Galston says, 'intrinsic goods,' along with the awareness that these goods may come into conflict. As how we resolve conflicts between intrinsic goods is central to our identity, both as individuals and as members of social groups, the liberty we exercise in doing so (expressive liberty) 'bears directly on questions of identity,' and so it 'requires some basis for arguing that the liberties it comprises are weighty relative to others' (2002, p. 28n1, p. 38). Expressive liberty therefore enjoys an 'elevated status,' and so 'protection' of the sphere of the 'intellect and spirit' 'against unwarranted intrusion represents the most fundamental of all human liberties' (2005, p. 65). Expressive liberty is the most fundamental liberty because, for Galston, 'liberalism is about the protection of diversity' (2017 [2002], p. 9). That is why the state must discharge what he calls 'a burden of proof whenever it seeks to restrict expressive liberty' (2005, p. 3).

Galston not only argues that expressive liberty is more weighty than other forms of negative freedom. He goes on to say that people are not free to do as they please when what they please to do is in conflict with the requirements of expressive liberty:

more liberty (understood as the capacity to act without external impediments) is not necessarily preferable to less liberty, so understood. When we move from this understanding of liberty to a more plausible conception that preserves its standing as an affirmative value, we observe that liberty shouldn't be understood as the freedom to do whatever we want, but rather the freedom to act as long as we respect the rights, properly understood, of others. (ibid., p. 17)

Galston is arguing that we are not free to do whatever we want, that freedom thus understood is not an affirmative value, but also that this conclusion follows from value pluralism. Value pluralism defines for us the broad range of legitimate 
variation' (ibid., p. 2); and reveals for us 'the range of choiceworthy human lives' and 'intrinsic goods' for us to choose between (2002, pp. 37-8). While value pluralism sets before us these intrinsic goods, the freedom to do as we please is not one of them: 'values must pass a goodness test [...] [and] Berlin's account of liberty does not pass that test' (2005, p. 17). If freedom is to be an affirmative value, it cannot be the freedom to do whatever we want. We are not free to be intolerant, cruel, and tyrannical, for example. There is only a certain range of things we are free to do, the parameters of which are, Galston maintains, determined by value pluralism.

Galston's argument is that the requirement to protect negative freedom, understood as the freedom to do as we please, is not a (affirmative) value. But have we been given a compelling reason as to why that is the case? Galston shows that the requirement to protect negative freedom may be in conflict with expressive liberty (and therefore the toleration of diversity as well), but value pluralism entails that reasons for action do come into conflict with each other, and that this is not in itself reason to assume that what we thought to be a reason for action in fact is not. Indeed, Galston can advance his argument against the freedom to do as we please only as a weak value pluralist. His conclusion is that the requirement to protect negative freedom is a value insofar as it does not violate expressive liberty: we are free to do as we please only if what we please to do is compatible with the toleration of diversity (see Fives 2021, p. 249). This could be the case only if reasons for action are rankordered, according to which expressive liberty has priority as a general rule over the freedom to do as we please. Galston, therefore, offers a pluralist approach to moral conflict, only to introduce a general rule for resolving some of those conflicts. And as we know, this is precisely what Raz does in his version of weak value pluralism.

Galston's efforts to avoid the unsettling implications of Berlin's strong value pluralism entail his moving to a weak version of value pluralism. But he is not the only one to have engaged in such a project. George Crowder is another value pluralist who, like Galston, maintains that the requirement to protect negative freedom ceases to be a value when it clashes with an overriding liberal commitment. However, for Crowder the relevant liberal commitment is not toleration but autonomy. Crowder begins from a sense of dissatisfaction with the way Berlin draws the connection between value pluralism and freedom. As we saw, Berlin maintains that the requirement to protect negative freedom is a moral commitment because we are faced with the agony and necessity of choosing between conflicting ends and claims. Crowder draws a different conclusion from the fact of value pluralism: namely, 'we need to be autonomous' (2004, p. 165). And Crowder's contention is that his own defense of autonomy is, for a number of reasons, a value pluralist one: it does not presume a 'fixed conception of the true self,' 'it does not take the pursuit of any particular good as its goal,' and it does not assume a 'single correct ranking of incommensurable values' (ibid., p. 86). Indeed, 'the existence' of 'incommensurable options' is, he says, 'implied by the valuing of personal autonomy' (ibid.). Nonetheless, while Crowder remains a value pluralist, his is a weakened version of pluralism.

Crowder readily admits 'that this argument depends upon a significant assumption,' for autonomy is a necessity only 'if to "cope well" with choices means to choose for "a good reason" (ibid., p. 165). Is such an assumption compatible with value pluralism? It is, he concedes, surprising for a value pluralist to accord 'a 
universal privilege to a single good,' and yet although he emphasizes that, within his proposed framework, 'personal autonomy will be prominent but not always overriding,' nonetheless he concludes that the 'great diversity of ways of life [...] will have in common a respect for personal autonomy' (ibid., p. 169). Indeed, he is happy to conclude that 'it is at least arguable that the most important of all liberal goods is personal autonomy rather than [Berlin's] negative liberty or [Galston's] toleration' (ibid., p. 85). There are, for Crowder, a number of ways in which autonomy is more important than negative freedom. First, autonomous choice has a higher value than choice simpliciter: the rational choice between options is not 'merely one value among others,' because it is 'needed to organize choices among incommensurable goods,' and in its absence 'choices would be arbitrary, incoherent and perhaps selfdefeating' (ibid., p. 165). Second, lives based on non-autonomous choice are, he believes, 'undesirable.' If we value the diversity of goods revealed to us by value pluralism, we will see that 'arbitrary, incoherent and perhaps self-defeating' choices 'fail to do justice to, or take seriously, the goods they purport to value' (ibid.; see also p. 167). Third, there is no reason why we should be tolerated when we make non-autonomous choices. What is called for is "not $[\ldots]$ the toleration of multiple ways of life without regard to their content, but [...] the promotion of those ways of life which value personal autonomy' (ibid., p. 164; see also p. 169). Fourth, and of greatest significance for our purposes, Crowder concludes that we are not 'truly free' if our negative freedom is incompatible with our autonomous choice: 'for a person's life to be truly free, her actions must be "her own" in a stronger sense than that allowed by negative liberty. She must be prepared to take a critical view of her own desires, acting only on those she truly owns' (ibid., p. 85).

Crowder wants to distance himself from Berlin by maintaining that the requirement to protect negative freedom is not the most important of all moral commitments. Of course, as I have already argued, I do not think Berlin ever claims that the requirement to protect negative freedom is preeminent in this way, and this is so because he remains a strong value pluralist. However, Crowder obviously does wish to identify the most important of all moral commitments. He contends that autonomy is not merely one reason for action among others. Indeed, as a general rule, we can give it priority over others, including negative freedom. It also follows, whenever the freedom to do as we please clashes with autonomy, the former is cancelled or eliminated: that is why he assumes that a non-autonomous life is not truly free. And as that is the case, Crowder's line of argument is in parallel with Galston's: both are offering weak versions of value pluralism. They each assume we are not free to do as we please, when what we please to do is incompatible with autonomy (Crowder) or toleration (Galston).

But because they both reject Berlin's strong value pluralism, they each are open to the same criticism. Berlin has pointed out the paradox created when we think that we are not free to do what is irrational or immoral. It is the paradox of concluding that, when we remove options from others, we have not restricted their liberty in any way. We have not restricted liberty (it is argued) when we prevent extremist violence by threats of coercive force, including when we do so for the good of the extremist. Such a line of thought makes itself blind to the moral wrongs committed in these situations. Not only is it paradoxical, the disagreement between those who think 
of freedom in this way is a further cause for concern. Crowder and Galston cannot agree whether we are free only to be autonomous or only to be tolerant. Skepticism is the only reasonable response given that no compelling argument has been offered for either version of this argument.

\section{Political realism and modus vivendi}

My thesis is that Berlin provides a strong version of value pluralism, one important implication of which being we are free to do as we please. Yet it may seem that two important recent developments within value pluralism call that thesis into question, namely what Williams says about political realism and John Gray's points about modus vivendi. Could a strong value pluralist make a reasonable case for either the conclusion that we are not free to do anything that calls into question an acceptable solution to the problem of legitimacy, or the conclusion that an illiberal society can crowd out and exclude altogether negative freedom as a reason for action?

Williams identifies "the "first" political question in Hobbesian terms as the securing of order, protection, safety, trust, and the conditions of cooperation' (2005, p. 3 ). Thus, meeting the 'basic legitimation demand' is what distinguishes a legitimate from an illegitimate State, and it "can be equated with there being an "acceptable" solution to the first political question' (ibid., p. 4). Does it then follow that no one can be said to be free to do anything that calls into question this 'acceptable solution'? I do not think so, and this is because of the distinction Williams makes between primitive freedom and rights of liberty. Primitive freedom is conceptualized as not 'being in someone else's power,' 'the condition of life without terror,' the 'absence of constraint,' and being free to do 'anything he happens to want' (ibid., p. 60, p. 61, p. 83, p. 116). Primitive freedom is thus none other than Berlin's conception of negative freedom. It is the freedom to do as we please, and more besides. Williams also emphasizes that it is one among many freedoms, for in addition there are various rights of liberty: i.e. 'more sophisticated conceptions of freedom,' including the 'freedom from unemployment and want' (ibid., p. 61), as well as toleration (ibid., p. 133), and an acceptance of 'censorship only on the narrowest of grounds' (ibid., p. 144). Primitive freedom, therefore, is distinct from rights of liberty. According to Williams, although no one wishes to have their primitive freedom restricted, nonetheless, he says, "no sane person can think that he has a right against others to what is demanded by his primitive freedom as such (i.e. to anything he happens to want)' (ibid., p. 83). There is a distinction here between our freedom to do as we please and what liberties we can claim as a right. But because we do not have a right to do as we please, does it follow that intolerant extremists, for example, are not free to do as they please? Does it follow that we are not free to do as we please because the requirement to protect freedom thus understood is not a genuine moral commitment? Again, I do not think so.

When there is a conflict between our freedom to do as we please and our rights of liberty, it does not follow that the former is excluded, overridden, or cancelled. This is the case because Williams, as a strong value pluralist, accepts that we have no general rule for the resolution of such conflicts. This is clear when we consider what 
Williams has to say about the 'critical theory principle.' Based on what he refers to as the 'universalism' of cruelty and fear, Williams proposes a type of reflection that can be critical of our taken-for-granted assumptions and practices, including what we take to be rights of liberty. The 'critical theory principle' states that 'the acceptance of a justification does not count if the acceptance itself is produced by the coercive power which is supposedly being justified' (ibid., p. 6). And he concludes that legitimation cannot be "simply an account of successful domination. It has to be something in the mode of justifying explanation or legitimation: hence the BLD [basic legitimation demand]' (ibid., p. 5). Where does the basic legitimation demand derive its normative force? It comes from the value of primitive freedom: the value of not being in someone else's power, the condition of life without terror. If primitive freedom is one of the bases on which we can call into question any particular acceptable solution to the legitimacy problem, and thus the network of rights claims characterizing that solution, then it is not the case that rights of liberty have priority, as a general rule, over primitive freedom.

Hence, Williams's political realism does not require rejecting the thesis that we are free to do as we please. What about Gray's arguments for modus vivendi? Gray's starting point is that if 'value pluralism is true all the way down,' then it is true for all values (2013 [1996], p. 202). He develops two lines of argument from that starting point. One is that, as there is no common measure of value, as a result there is no ground for a 'liberal political morality in which the promotion of negative liberty has pre-eminence' (2013 [1996], p. 67; see Gray 1998, p. 19). The second line of argument is that, because of value pluralism, competing values may 'crowd one another out, exclude one another altogether, or belong to ways of life that are by necessity uncombinable' (1998, p. 20). Behind each of these arguments is the idea that commitment to a liberal form of life is 'a groundless one, which nothing in reason compels us to make' (2013 [1996], p. 202). Gray is right to point out that, for Berlin, there are conflicts not only between values, but also between value systems and ways of life. Hence, in his essay on Machiavelli, Berlin reaches the following 'conclusion of the first importance:' namely, that 'the belief that the correct, objectively valid solution to the question of how men should live can in principle be discovered, is itself in principle not true' (1981 [1972], pp. 66-7). For Gray, there are many ways in which to live; not all of them give priority to or even include the requirement to protect negative liberty; and we have no rational grounds for choosing between them. At other times, the line of argument varies, but the conclusion remains the same: there is no rational basis to insist on the reasonableness of a given liberal resolution to conflicting values. Thus, he maintains that liberalism, if it is accepted, has 'no universal claim on reason' (2013 [1996], p. 37); and also that 'liberal institutions are merely one variety of modus vivendi, not always the most legitimate' (1998, p. 34).

I do not wish to question Gray's contention that there is no one way to resolve moral conflicts of this sort, as I take it that this is the upshot of Berlin's strong value pluralism. Also, I am not interested here in Gray's claim that liberals cannot show that the requirement to protect negative freedom is the pre-eminent moral commitment. That is not what I have been arguing, and I do not think it is what Berlin argues either. What I am interested in is Gray's claim that the freedom to do as we 
please may be crowded out or excluded altogether in a particular society. How can this be? There is, he says, a 'universal minimum morality which specifies universal goods and bads that mark the boundaries of a worthwhile human life,' and that minimum rules out slavery and genocide as 'insuperable obstacles to a worthwhile life' (ibid., p. 23). However, in what Galston points out is a departure from Berlin's views (Galston 1999, p. 772), Gray's universal minimum morality does not require protection of negative freedom: on the one hand, he says 'it does not dictate distinctive liberal freedoms of the press, religion or autonomous choice;' and on the other, he rejects the view 'that negative freedom and personal autonomy are values in the absence of which no worthwhile human life is possible' (Gray 1998, p. 33, p. 34).

In evaluating his position, let us start with the claim that, when reasons for action come into conflict, there are no rational grounds for their resolution. As we have already seen, Berlin (writing with Williams) maintains that we $d o$ have rational resources for making such a decision. Crowder describes this argument as a contextualist one (Crowder 2009). I think this goes too far, as it is not the context as such that is decisive for Berlin but the practical reasoning engaged in by those faced with difficult decisions in specific contexts. Yet Berlin does accept that, in different situations, at different times, with different arguments offered, the legitimate restrictions of individual freedom also will differ. That is, Berlin's argument is that what counts as legitimate restrictions of individual freedom may rightly differ. However, it does not follow that, as Gray maintains, there is no rational basis for our resolution of these moral conflicts. Berlin's point is that, while there is no general rule for doing so, we can engage in practical reasoning about how to resolve moral conflicts.

Gray also claims that the requirement to protect negative freedom is not universal. Hence, liberal and illiberal regimes need not be seen as rivals, he says, and liberal regimes and 'some (non-fundamentalist) illiberal regimes' are simply 'alternatives' (1998, p. 24). It is the case that an illiberal regime will differ from liberalism not only in the specific options that it removes (say, the option of practicing some specific religion, or of forming specific types of personal relationships, and so on) but also in many cases because it will remove far more options than any liberal regime would. All that may be true, but it does not follow that the requirement to protect negative freedom ceases to be a reason for action in the illiberal modus vivendi. Gray says that different cultures are not themselves incommensurable, as relativists would argue, but rather they 'are different ways of settling universal conflicts' (2006, p. 328). However, we can accept that an illiberal regime settles conflicts regarding negative freedom in a different way to a liberal society, and certainly that an illiberal regime will not give priority to this reason for action. But it is only because Gray does not include the requirement to protect negative freedom in his list of universal goods that it becomes possible to talk of a 'decent' illiberal modus vivendi where the requirement to protect negative freedom is simply excluded and crowded out altogether as a value. If he did recognize the requirement to protect negative freedom as a universal, then there would be no way of justifying a regime that excluded the value altogether. And it is important to stress that strong value pluralists can account for such universals without falling into contradiction and thinking of certain reasons for action as pre-eminent. This is the case with Berlin and with Williams. It is also true of Stuart Hampshire, who talks about universal rules of justice designed 
to protect us from universal evils. As Hampshire makes clear, these universals do not simply trump more particular considerations, such as the virtues of a particular way of life. Rather, the latter offer distinctive interpretations of the former (1989, p. 73). Therefore, we can pick out a universal feature of morality without assigning it the status of conclusive reason for action. Even if the requirement to protect negative freedom is a universal value, it can come into conflict with, and possibly be overridden by, other reasons for action.

As Gray says, ethical theory cannot 'disregard the evidences of ethical life' (1998, p. 26). But when we do look at the evidence, there is little support there for Gray's position. What we have seen so far is that negative freedom is always restricted, as there is always some infringement of choice, but the requirement to protect negative freedom would also seem to be a reason for action nonetheless. That is, the fact that options are removed does not take from negative freedom's status as a moral commitment; indeed, it is because the requirement to protect negative freedom is a moral value that the removal of options stands as a wrong. Therefore, even in an illiberal modus vivendi, our commitment to protect negative freedom is a reason for action, one among others, according to which we are free to do as we please. Berlin's position is that legitimate restrictions of options rightly vary depending on the conclusions of our practical deliberations, but also that such restrictions do violate freedom: they are wrong. Gray's reflections on the possible merits of an illiberal modus vivendi have not challenged that point.

\section{Concluding remarks}

I have been examining what I have called the unsettling implication of Berlin's strong value pluralism, namely, that a wrong is done when we are prevented from doing as we please, and this is the case regardless of what it is we please to do. I have also looked at the efforts of weak value pluralists to avoid this unsettling implication. My argument has been that, in each case, the effort has failed. It does not follow that weak value pluralists are wrong to maintain that the freedom to do as we please should be restricted. It is rather that they depart from strong value pluralism when they maintain that, in intervening in these ways, no wrong is done. Various reasons can be offered for restricting negative freedom. Liberals maintain that we should be prevented from acting intolerantly or from undermining autonomy. Arguments for the restriction of negative freedom can also be drawn from the values of an illiberal society, where it is maintained that we should be prevented from acting in ways that are incompatible with the shared values of our (illiberal) community. In this paper, I have not attempted to show that such infringements of liberty could never be justified. Rather, my argument has been that, in each case, a wrong is done, for the simple reason that, in each case, we are prevented from doing what we please. I do not mean to suggest that the wrongs done are equal in significance, or that there is no possible justification for such wrongs in any of these scenarios. The significance of the wrong will depend on an all-things-considered judgement, a judgement that will take on board the requirement to protect the freedom to do as we please as well as any other conflicting reason for action. That is, a judgement is 
called for in response to a genuine moral conflict. In many cases, what we have is as a clash between our primitive freedom and our rights of liberty. Sometimes our freedom to do as we please should be restricted so as to better guarantee rights of liberty, but such a restriction is still a wrong.

Funding Open Access funding provided by the IReL Consortium.

\section{Declarations}

Conflict of interest There are no conflicts of interest related to this piece of work.

Open Access This article is licensed under a Creative Commons Attribution 4.0 International License, which permits use, sharing, adaptation, distribution and reproduction in any medium or format, as long as you give appropriate credit to the original author(s) and the source, provide a link to the Creative Commons licence, and indicate if changes were made. The images or other third party material in this article are included in the article's Creative Commons licence, unless indicated otherwise in a credit line to the material. If material is not included in the article's Creative Commons licence and your intended use is not permitted by statutory regulation or exceeds the permitted use, you will need to obtain permission directly from the copyright holder. To view a copy of this licence, visit http://creativecommons.org/licen ses/by/4.0\%.

\section{References}

Berlin, Isaiah. 2004 [1958]. "Two Concepts of Liberty.” In Liberty, ed. Henry Hardy, 166-217. Oxford: Oxford University Press.

Berlin, Isaiah. 2004 [1969]. "Introduction.” In Liberty, ed. Henry Hardy, 3-54. Oxford: Oxford University Press.

Berlin, Isaiah. 1981 [1972]. “The Originality of Machiavelli.” In Against the Current, ed. Henry Hardy, 25-79. Oxford: Oxford University Press.

Berlin, Isaiah and Williams, Bernard. 1994. "Pluralism and Liberalism: A reply." Political Studies XLI: 306-09.

Crowder, George. 2004. Isaiah Berlin: Liberty and Pluralism. Cambridge: Polity.

Crowder, George. 2009. “A Berlinian Education.” In The Book of Isaiah: Personal Impressions of Isaiah Berlin, ed. Henry Hardy, 216-22. Woodbridge: Boydell Press.

Fives, Allyn. 2017. Evaluating Parental Power: An Exercise in Pluralist Political Theory. Manchester: Manchester University Press

Fives, Allyn. 2018. "Paternalism and Moral Conflict: A pluralist analysis of parental power." The Journal of Political Power 11(2): 151-64

Fives, Allyn. 2019. "The Freedom of Extremists: Pluralist and Non-pluralist Responses to Moral Conflict." Philosophia 47(3): 663-80.

Fives, Allyn. 2020. Judith Shklar and the Liberalism of Fear. Manchester: Manchester University Press

Fives, Allyn. 2021. "A Value Pluralist Defense of Toleration.” Philosophia 49(1): 235-54

Galston, William A. 1999. "Value Pluralism and Liberal Political Theory." American Political Science Review 93 (4): 769-78.

Galston, William A. 2002. Liberal Pluralism: The Implications of Value Pluralism for Political Theory and Practice. Cambridge: Cambridge University Press.

Galston, William A. 2017 [2002]. "Value Pluralism and Political Liberalism." In Philosophical Dimensions of Public Policy, eds. Verna V. Gehring and William. A. Galston, pp. 7-13. New York: Routledge.

Galston, William A. 2005. The Practice of Liberal Pluralism. Cambridge: Cambridge University Press. 
Galston, William A. 2010. "Realism in Political Theory." European Journal of Political Theory 9 (4): 385-411.

Gray, John. 1998. Where Pluralists and Liberals Part Company. International Journal of Philosophical Studies 6 (1): 17-36.

Gray, John. 2006. "Reply to Critics." Critical Review of International Social and Political Philosophy 9 (2): 323-47.

Gray, John. 2013 [1996]. Isaiah Berlin: An Interpretation of his Thought, second edition. Princeton: Princeton University Press.

Hampshire, Stuart. 1989. Innocence and Experience. Cambridge, MA: Harvard University Press.

Kekes, John. 1993. The Morality of Pluralism. Princeton: Princeton University Press.

Midlarsky Manus I. 2011. Origins of Political Extremism: Mass Violence in the Twentieth Century and Beyond. Cambridge: Cambridge University Press.

Mill, John Stewart. 1985 [1859]. On Liberty, ed. Himmelfarb, Gertrude. London: Penguin.

Raz, Joseph. 2009 [1975]. Practical Reason and Norms, second edition. Oxford: Oxford University Press.

Raz, Joseph. 2009 [1979]. The Authority of Law, second edition. Oxford: Oxford University Press.

Raz, Joseph. 1986. The Morality of Freedom. Oxford: Clarendon Press.

Schmid, Alex P. 2013. Radicalisation, De-Radicalisation, Counter-Radicalisation: A Conceptual Discussion and Literature Review. The Hague: ICCT.

Williams, Bernard. 1965. "Ethical Consistency." Proceedings of the Aristotelian Society 39 (suppl.): 103-24.

Williams, Bernard. 1981 [1979]. "Conflict of Values." In Moral Luck, 71-82. Cambridge: Cambridge University Press.

Williams, Bernard. 2005. In the Beginning was the Deed: Realism and moralism in political argument, ed. Geoffrey Hawthorn. Princeton and Oxford: Princeton University Press.

Williams, Bernard. 2009. "Tributes: Bernard Williams.” In The Book of Isaiah: Personal Impressions of Isaiah Berlin, ed. Henry Hardy, 21-24. Woodbridge: Boydell Press.

Publisher's Note Springer Nature remains neutral with regard to jurisdictional claims in published maps and institutional affiliations. 